\title{
Right ventricle collapse secondary to hepatothorax caused by diaphragm rupture due to blunt trauma
}

\author{
Mustafa Topuz, M.D., ${ }^{1}$ Mehmet Cihat Ozek, M.D. ${ }^{2}$ \\ ${ }^{1}$ Department of Cardiology, Adana Numune Training and Research Hospital, Adana \\ ${ }^{2}$ Department of General Surgery, Turhal State Hospital, Tokat
}

\begin{abstract}
Traumatic diaphragm ruptures occur frequently after motor vehicle accidents through penetrating traumas. In $90 \%$ of the patients, traumatic diaphragm rupture commonly coexists with other organ injuries. Posteroanterior chest $\mathrm{x}$-ray, computed tomography, magnetic resonance imaging, upper gastrointestinal system contrast-enhanced examinations, and thoraxoscopy/laparoscopy are several modalities which can be used for diagnosing traumatic diaphragm rupture in clinical practice. A case of right ventricle collapse secondary to hepatothorax caused by diaphragm rupture was presented in this study. Patient was diagnosed by posteroanterior chest $\mathrm{x}$-ray and computed tomography. Emergency surgery was planned due to hemodynamic instability. When mechanical pressure on the right ventricle disappeared, hemodynamic improvement was observed simultaneously.
\end{abstract}

Key words: Mechanical stress; right ventricle collapse; traumatic diaphragm rupture.

\section{INTRODUCTION}

Traumatic diaphragm rupture (TDR) is a rare, life-threatening clinical condition occurring after an excessive increase in intra-abdominal pressure. ${ }^{[1]}$ It has been reported in $1-7 \%$ of the patients with major blunt traumas and $10-15 \%$ of the patients suffering from penetrating traumas. ${ }^{[2,3]}$ Over $90 \%$ of patients, TDR exist with concomitant organ injuries, which is the main factor leading to death or major complications. ${ }^{[4,5]}$ Intrathoracic herniation of abdominal organs following diaphragmatic injury is a rare clinical condition difficult to diagnose. ${ }^{[6]}$ Stomach, spleen and colon are the most frequently herniated organs due to the more occurrence of left sided diaphragmatic ruptures with a reported ratio of 25 to 1.5. ${ }^{[2]}$

In this study, a case of a 55-year-old woman with right ventricle collapse secondary to hepatothorax caused by right dia-

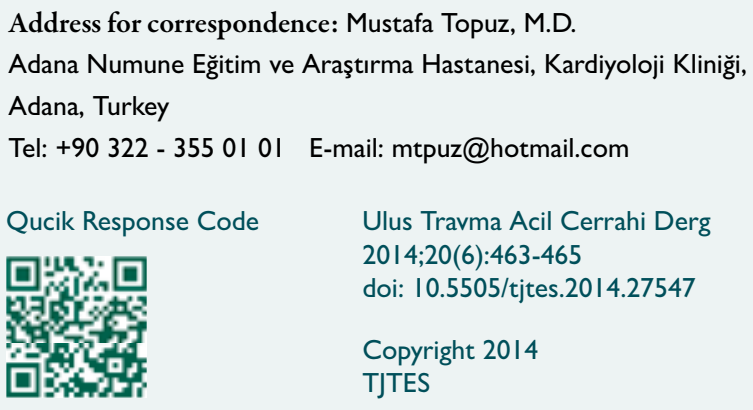

phragm rupture following an isolated blunt thoracic trauma was reported.

\section{CASE REPORT}

A 55-year-old women was admitted to our emergency department about twenty-five minutes after having a traffic accident. Although she had a history of hypertension, she was hemodynamically compromised on admission. Patient's heart rate was 118 beats/min with sinus tachycardia, blood pressure was $80 / 50 \mathrm{mmHg}$, and pulse arterial oxygen saturation was $83 \%$ without taking $\mathrm{O}_{2}$. Jugular venous distention and abdominal tenderness with palpation were present. She had difficulty in breathing and her respiratory sounds decreased during the auscultation of the right hemithorax. Chest X-ray demonstrated elevated right hemi-diaphragm (Fig. Ia). Thorax CT was consequently performed, showing the rupture of right hemi-diaphragm and dislocation of liver into the right hemithorax (Fig. Ib). Due to findings of cardiac tamponade, the patient was urgently transferred to the operating room and underwent an exploratory midline laparotomy in order to remove the tamponade. Right sided diaphragmatic rupture and intra-thoracic herniation of the liver causing mechanical compression of the right ventricle was detected during the operation. Relocation of the liver into the abdominal cavity was performed, and then, the diaphragm was sutured and a chest-drain was placed. After surgical relocation of the liver 

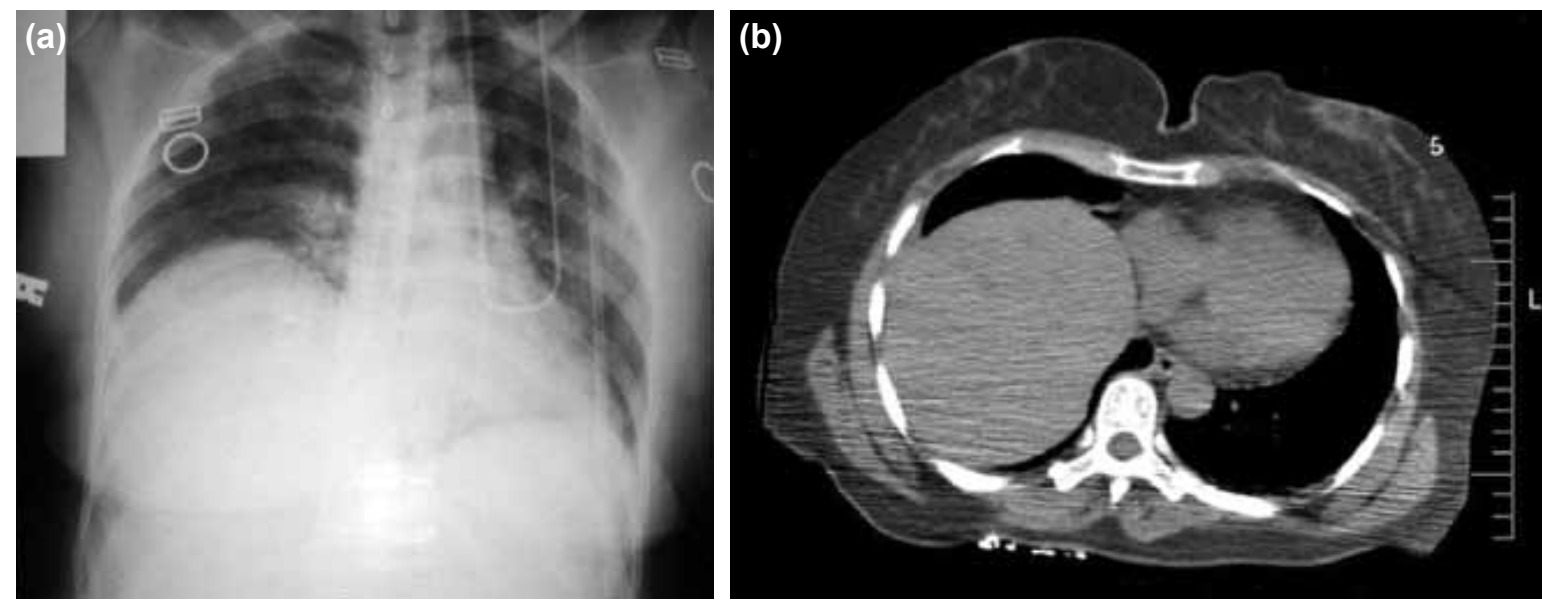

Figure 1. (a) Chest radiography of the patient showing elevated right diaphragm. (b) Chest computed tomography image of the patient showing the right ventricular collapse.

into the abdominal cavity and repair of the diaphragmatic rupture, chest X-ray was repeated showing the normal position of right diaphragmatic border. Postoperatively, the patient's clinical course was good and she was discharged on the fifth day of operation.

\section{DISCUSSION}

Pressure gradient between the abdominal cavity and thorax is $2-10 \mathrm{mmHg}$. When blunt traumas exceed the threshold of the diaphragm elasticity, ruptures occur. ${ }^{[7]}$ These ruptures are frequently seen on the left side of the diaphragm ${ }^{\left[{ }^{[8]}\right.}$ Clinical characteristics of patients with diaphragmatic rupture are silent and non specific. In the acute phase, patients are usually admitted to the emergency setting with co-existing injuries that may obscure the diagnosis, which is responsible for major complications and deaths. Thoracic pain, cough, tachypnea and dyspnea are among the most commonly reported symptoms. ${ }^{[9]}$

Posteroanterior (PA) chest x-ray, computed tomography (CT), magnetic resonance imaging (MRI), upper GIS contrast-enhanced examinations, and thoraxoscopy/laparoscopy can be used in TDR diagnosis. PA chest $x$-ray is a simple and valid test diagnostic in $66 \%$ of the patients. These chest $x$-rays display hemi-diaphragm elevation, gas shadow in the thoracic cavity, absence or suppression of diaphragm shadow, and mediastinal shift. ${ }^{[10]}$ On the other hand, its preoperative diagnostic value is limited in the presence of concomitant pleural effusion, atelectasia, and pulmonary contusion. When the diagnosis of TDR is doubtful, the preferable radiodiagnostic method is CT. Abdominal and thoracic computed tomography scans remain highly specific methods for the establishment of a preoperative diagnosis in the acute care setting. ${ }^{[1]}$

Right sided diaphragmatic ruptures are rare conditions presenting with non specific clinical and radiological findings.
Therefore, it is associated with high mortality rates. Hepatothorax represents a rare and severe complication of right diaphragmatic rupture. ${ }^{[12]}$ Herniation of the liver into the thoracic cavity may compromise pulmonary and cardiovascular functions through severe atelectasis of the right lung and compression of the mediastinum.

Treatment is possible with laparotomy, thoracotomy or a combined approach. Preferred technique can vary between patients. Surgical repair of the hepatothorax should be urgent and consist liver relocation and repair of the diaphragmatic defect through a trans-thoracic or trans-abdominal approach. ${ }^{[3]}$ The use of interrupted or continuous non-absorbable suturing along with the intra-thoracic placement of chest tubes represents classical strategy.

\section{Conclusion}

A case of right diaphragmatic rupture with severe hepatothorax complicated by cardiovascular collapse owing to compression of the mediastinum was presented here. Cardiac tamponade is a life-threatening condition. When clinicians encounter cardiac tamponade, they are often directed to pericardial effusion due to major vascular injury or cardiac contusion after blunt trauma. Thus, preoperative detection of concomitant pathology such as hepatothorax because of a diaphragmatic rupture is crucial to understand the underlying cause for development of tamponade after blunt trauma. Therefore, physicians have to maintain a high level of clinical suspicion when they encounter patients with sudden onset of respiratory distress or upper abdominal symptoms after a major blunt thoracic or abdominal trauma. In this case, right sided diaphragmatic rupture was complicated by cardiovascular collapse, leading it to be diagnosed and treated as fast as possible. The success of therapy in TDR patients is directly related to concomitant organ injuries.

Conflict of interest: None declared. 


\section{REFERENCES}

1. Rashid F, Chakrabarty MM, Singh R, Iftikhar SY. A review on delayed presentation of diaphragmatic rupture. World J Emerg Surg 2009;4:32.

2. Baek SJ, Kim J, Lee SH. Hepatothorax due to a right diaphragmatic rupture related to duodenal ulcer perforation. World J Gastroenterol 2012;18:5649-52. CrossRef

3. Meyers BF, McCabe CJ. Traumatic diaphragmatic hernia. Occult marker of serious injury. Ann Surg 1993;218:783-90. CrossRef

4. Rodriguez-Morales G, Rodriguez A, Shatney $\mathrm{CH}$. Acute rupture of the diaphragm in blunt trauma: analysis of 60 patients. J Trauma 1986;26:438-44. CrossRef

5. Voeller GR, Reisser JR, Fabian TC, Kudsk K, Mangiante EC. Blunt diaphragm injuries. A five-year experience. Am Surg 1990;56:28-31.

6. Kozak O, Mentes O, Harlak A, Yigit T, Kilbas Z, Aslan I, et al. Late presentation of blunt right diaphragmatic rupture (hepatic hernia). Am J Emerg Med 2008;26:638.e3-5.

7. Gelman R, Mirvis SE, Gens D. Diaphragmatic rupture due to blunt trauma: sensitivity of plain chest radiographs. AJR Am J Roentgenol 1991;156:51-7. CrossRef

8. Mansour KA. Trauma to the diaphragm. Chest Surg Clin N Am 1997;7:373-83.

9. Shreck GL, Toalson TW. Delayed presentation of traumatic rupture of the diaphragm. J Okla State Med Assoc 2003;96:181-3.

10. Aronoff RJ, Reynolds J, Thal ER. Evaluation of Diaphragmatic injuries. Am J Surg 1982;144:571-5. CrossRef

11. Killeen KL, Shanmuganathan K, Mirvis SE. Imaging of traumatic diaphragmatic injuries. Semin Ultrasound CT MR 2002;23:184-92. CrossRef

12. Porcelli M, Prychyna O, Rosenthal A, Decostanza J. Hepatothorax: a rare outcome of high-speed trauma. Case Rep Emerg Med 2011;2011:905641.

\section{OLGU SUNUMU - ÖZET}

\section{Künt travma nedeniyle oluşan diyafram rüptürünün sebep olduğu hepatotoraksa sekonder sağ ventrikül kollapsı \\ Dr. Mustafa Topuz, ${ }^{1}$ Dr. Mehmet Cihat Ozek}

${ }^{1}$ Adana Numune Eğitim ve Araştırma Hastanesi, Kardiyoloji Kliniği, Adana; ${ }^{2}$ Turhal Devlet Hastanesi, Genel Cerrahi Kliniği, Tokat

Travmatik diyafram rüptürü genellikle motorlu araç kazasına bağlı penetran travmalar sonucunda meydana gelir. Olguların \%90'ında diğer organ yaralanmaları ile beraberdir. Direkt grafi, bilgisayarlı tomografi, manyetik rezonans görüntüleme, kontrastlı üst gastrointestinal sistem incelemesi ve torakoskopi/laparoskopi klinikte tanı amaçlı kullanılan yöntemlerdir. Biz bu olguda diyafram rüptürü sonrası karaciğer herniasyonuna sekonder gelişen sağ ventrikül kollapslı bir hasta sunduk. Hastanın tanısı arka-ön akciğer grafisi ve bilgisayarlı tomografi ile konuldu. Hemodinamisi kötü olan hastaya acil cerrahi planlandı. Sağ ventrikül üzerindeki mekanik basınç ortadan kaldırıldı̆ında eş zamanlı hemodinamik iyileşme gözlendi.

Anahtar sözcükler: Mekanik stress; sağ ventrikül kollapsi; travmatik diyafram rupture.

Ulus Travma Acil Cerrahi Derg 20I4;20(6):463-465 doi: 10.5505/tjtes.20।4.27547 